\title{
Gondolkodás- és képességfejlesztés: kihívások és megoldások a SAILS projektben
}

A SAILS (Strategies for Inquiry Learning in Science) projekt az Európai Unió szintjéról indult kezdeményezés, amelyben innovációs kihivásokat támasztott résztvevók számára intézményeken belül is, elérve a tanári közösségeket, formálva a személyes tanitási gyakorlatot és magát a tanulási folyamatot (Csapó, Csíkos és Korom, 2016). A 21. század változó világában új készségek szükségesek a

hatékony gazdasági és társadalmi részvételhez. A nemzetközi versenyképesség kihivásai felértékelték a természettudományos és

technológiai tudást. Az oktatási rendszerek komplexitása és a változásokkal szembeni inerciája azonban feszültségeket okoz az

elvárt tudás és képességek, valamint az iskolákban valóban megszerzett tudás között. A SAILS projekt olyan megoldásokat és

mintákat kinál, amelyek képesek mikro-szintú változásokat generálva, alulról szervezôdó módon segíteni egy új pedagógiai

szemléletmód kialakitását. A természettudományos tudás és a 21. századi készségek formálását a fejlesztô értékelés módszerével az egyes tanuló szintjén, az osztálytermi folyamatokat feltárva képes elósegíteni. A budapesti Közgazdasági Politechnikumban több SAILS tanulási egység adaptálása során kialakitott értékelési eszközök a gyakorlati megoldásokra is példaként szolgálhatnak. ${ }^{1}$

\section{A SAILS projekt mint innovációs kihívás}

\begin{abstract}
A SAILS projekt egyik legfontosabb hatása az, hogy az oktatás fejlesztésének elhanyagolt területével, az osztálytermekben zajló hétköznapi tanítási-tanulási folyamatokkal foglalkozik. Amint a projektben részt vevő angol kutatók arra már korábban rámutattak: „Rendszerszervezési szempontból az oktatáspolitika az osztálytermet fekete dobozként kezeli. Bizonyos inputokat megpróbálnak ide bejuttatni... ennek nyomán remélhetően megjelennek bizonyos outputok... De mi történik a dobozban?" (Black és Wiliam, 1998b, 139. o.)

A hazai pedagógusközösségben évek óta él egyfajta szkepszis a felülről jövő, újabb és újabb reformokkal szemben. Ha magának a rendszernek az átalakítását nem számítjuk, akkor a pedagógiai-módszertani megújítást célzó programok hatása nem tủnik sem mélyrehatónak, sem maradandónak. A kompetencia fogalma, a kompetencia-alapú oktatásra törekvés felemás eredményt hozott, magát a szót sem gyakran hallani az iskolák tantestületeiben, vagy ha mégis, többnyire negatív felhanggal. Újabban a tanári kompetenciák léte vagy nem léte, fejlesztése került előtérbe, ami kétségkívül időszerű törek-
\end{abstract}


vés, de a megvalósulása több kérdést is felvethet. Biztató azonban, hogy egyre inkább tetten érhetők a kisebb léptékü, alulról szerveződő változások, amelyek az érdeklődő és érdekelt pedagógusok egyéni vagy kollektív munkája révén formálják a tanítás-tanulás gyakorlatát. A SAILS projektben részt vevő pedagógusok és tanárjelöltek szembesültek a természettudományos nevelés megújításának kihívásaival, megismerkedtek lehetséges megoldások példáival, gyakorolták ezek alkalmazását. A kipróbált foglalkozások és a képzések tapasztalatai azt mutatták, hogy a résztvevők többsége elköteleződött a kutatásalapú tanítás és tanulás (Inquiry Based Science Education, IBSE) módszereivel kapcsolatban, illetve annak formatív értékelési gyakorlata mellett.

\section{Érték és értékelés}

A SAILS projekt hatásával kapcsolatos hipotézis megfogalmazása előtt néhány kérdést érdemes végiggondolni. Ezzel a módszerrel a tanulók tudásának másfajta minőségét kívánjuk fejleszteni. Másként irányítjuk a tanulási folyamatot, másféle tanulási környezetet és eszközöket alkalmazunk. Ezek az „inputok” minden bizonnyal megváltoztatják az „output” oldalt is, de éppen erről a legnehezebb megfelelő visszacsatolást kialakítani.

A kutatásalapú foglalkozások megtervezése sok időt és kreativitást igényel, de a klaszszikus tanári rutintól mégsem áll olyan távol, mint a tanulás eredményének megújult szemlélete. A kísérleti munka lépésről lépésre való irányításából való elmozdulás, a tanulói irányítás fokozatos felszabadítása néhány belső tanári meggyőződés feladását igényli, de a gátszakadást követően már önerösítő folyamattá is válhat. Hogy mindez nem önmagáért való üres technicizmus, azt a tanulói teljesítmény változásán lehetne lemérni. A SAILS programban kialakított keretrendszer gyakorlati okokból az alábbi értékelési területeket határozta meg:

- természettudományos vizsgálatok tervezése ('planning investigation')

- hipotézis kialakítása ('developing hypothesis')

- együttmüködés csoportban ('working collaboratively')

- koherens érvelés ('forming coherent arguments')

- természettudományos müveltség ('scientific literacy')

- természettudományos gondolkodás ('scientific reasoning')

Módszerként a formatív értékelés került a projekt középpontjába, ami a benne rejlő lehetőségek mellett bizonytalanságokat is okozott. A SAILS foglalkozásokban formailag leggyakrabban rangskálákat, ún. rubrikákat alkalmaztak a szerzők, ezekben az egyes teljesítményszinteket igyekeztek megfogalmazni és valamiféle fejlődési sorba rendezni. A módszer elönye, hogy a tanulók számára is érthetően kijelöli az aktuális szintet és a továbblépés lehetőségét. A tanár részben a tanórai megfigyelései alapján, részben a tanulói produktumok alapján dönt az egyes tanulók besorolásáról. Itt már támadhat némi bizonytalanság, mivel nem lehetséges valamennyi tanuló megfigyelése, az írásbeli munkák esetében pedig kétséges lehet az önálló munka. A csoportok értékelésében némileg pontosabb képet kaphatnánk, de akkor elvész az egyéni visszajelzések lehetősége. Az értékelt készségekkel kapcsolatos tanári tudás is inkább nevezhető véleménynek, mintsem objektív megállapításnak.

Folyamatos alkalmazásuk esetén ezek a formatív értékelési eszközök az adott pedagógus vagy csoport munkájában hatékony segítséget jelenthetnek. A visszajelzések igazodhatnak a tanulói szükségletekhez, segíthetik a lassabban haladókat, sikerélményhez juttathatják a jól teljesítőket. A SAILS foglalkozások adaptációja során tapasztalatom szerint szükséges volt a rubrikák finomszabályozása, azaz a csoport fejlődési szintjéhez és az aktualizált feladathoz való illesztése. E munka során a pedagógusnak végig kell 
gondolnia, mit várhat valójában a tanulóktól, milyen bizonyítékok alapján lesz képes minősítéseit kialakítani, és milyen formában hozza ezt a tanulók tudomására. Osztálytermi környezetben a tanulási folyamat irányítását hatékonyan segítheti ez az értékelési forma. Ráirányítja a figyelmet az éppen fejlesztendő készségekre, kitágítja a tanári eseményhorizontot a tananyag fogalmi körén túli világra, figyelembe veszi a tanulói személyiség komplexitását. Mindezek a hatások elmélyítik az érintettek pedagógiai kultúráját, segítik a tudatos és önirányító tanulóvá válást. Ha az egyes konkrét eszközelemek nem is, de ez a szemlélet mindenképpen megosztható egy intézmény pedagógus közösségében, vagy akár azon túl is.

\section{Szintek és szereplök}

A SAILS projekt, hasonlóan más EU-s vagy nemzeti kezdeményezésü modernizációs programhoz, egy rendkívül komplex és hierarchikus rendszerben jön létre (erről ld. Halász, 2009) és azon belül fejti ki hatását. Mind a program tartalmában, mind hatásában megjelennek a rendszer sajátosságai, előrevivő erői és korlátai.

Az oktatás és nevelés célját hajlamosak vagyunk valahol a tanulók körül (vagy éppen bennük) kijelölni, de azt látnunk kell, hogy az oktatási rendszert meghatározó gazdasági és társadalmi kölcsönhatások alakítják. A 21. században a tudásalapú társadalom új típusú készségeket vár el a munkavállalóktól, de a befektetett források hatékony megtérülésében is fokozottan érdekelt. A természettudományos és technológiai tudás nélkülözhetetlen a versenyképesség fenntartásához, de a korábbi módszerekkel már nem hozott kielégítő eredményeket. Az okok feltárása mellett elindult a változás menedzselése is, a Rocard-jelentést (Rocard, Csermely, Jorde, Lenzen, Walberg-Henriksson és Hemmo, 2007) követően számos, a természettudományos, müszaki és matematikai nevelés modernizációját célzó projekt indult (pl. FIBONACCI, Pathway, Pri-Sci-Net, PRIMAS, MASCIL, ASSIST-ME, SAILS). A projektek hatása különféle pályákon járta át az oktatási rendszereket, különféle mértékben érintve, bevonva vagy éppen mellőzve bizonyos alrendszereket.

A SAILS projekt a kutatók köréből indult, az itt felhalmozott tudás határozta meg a tartalmi elemeket és működési módokat. Ez a munka sem volt mentes vitáktól, de a munkacsomagok föbb irányvonalainak kialakítása után a projekt lendületet vett. A következő lépésben a foglalkozások (tanulási egységek, unitok) fejlesztésébe már tanárokat is bevontak, így a neveléstudomány és az osztálytermi munka szempontjai egymás mellé kerülhettek. Mivel a fejlesztők szemlélete sem volt egységes, a kialakított foglalkozásokban a kutatásalapú tanulás eltérő hangsúlyokkal jelent meg. Ez a sokféleség végül is gazdagította a programot. A tanár- és tanárjelölt-képzések ('in-service' és 'pre-service' tréningek) az egyetemi oktatók egy másik köre, valamint tréner tanárok bevonásával indult. Ezeken a képzéseken alkalmanként mint kutatást végzők már a tanulók is megjelentek.

A SAILS unitok kipróbálására az együttmüködő intézményekben már a tanárok és a tanulók együttes bevonásával, az értékelésre is kiterjedően került sor. Tapasztalatom szerint ekkor már a megvalósíthatóság dominált, ennek érdekében kisebb-nagyobb módosításokat kellett végrehajtanunk az eredeti foglalkozásterveken. A kutatói szint felé való visszajelzéseket a kipróbálásról készült esettanulmányokban tehettük meg. Ezek egy-egy foglalkozás esetében valamennyi kipróbálást összegző formában is elkészültek.

Az IBSE módszer lényegi kérdése a tanulók bevonásának mértéke és minősége. Nemcsak az a kérdés, mennyire élveznek önállóságot a kutatás során, hanem az is, mennyire tudatosak a fejlesztendő készségeik és azok értékelési módjai tekintetében. A tanárközpontú, ismeretátadó módszer mellé a szummatív, osztályozó értékelés társul, ami nem ad részletes képet sem az értékelt tanulói teljesítmény összetevőiről, sem azok meglévő 
fejlődési szintjéről, sem a továbblépés lehetőségéről. Az IBSE módszert támogatandó, tapasztalatom szerint a 7. évfolyamon már elkezdhető a készségekröl való beszélgetés, a fejlesztés jelentőségének felismertetése, a várható értékelési visszajelzés előkészítése. A foglalkozást követően a kapott értékelések tanulói értelmezésére is módot kaptak a tanulók. Fontos, hogy értsék és elfogadják a módszer célját a tanulók. A természettudomány tanulása iránti motivációt növelheti, ha a tanulók felismerik az ebben rejlö gondolkodás- és képességfejlesztési lehetőségeket (ld. Csapó, 2003), érdekeltté válnak a tartalomtól független önfejlesztésben. A korszerü és sikeres oktatási rendszerek egyik ismérve éppen az önszabályozó tanulóvá válás elősegítése (ld. D. Molnár, 2015), ehhez hozzájárulhat a kutatásalapú tanulás és a hozzá kapcsolódó készségfejlesztő értékelés.

\section{Az intézmény szintje}

A SAILS projektben részt vevő aktív és leendő tanárok révén olyan mikro-szintű változások indulhatnak el az iskolákban, amelyek a természettudományos órákon túl az intézmény szintjén is hatással lehetnek a pedagógiai folyamatokra. A tanári közösségek intenzív belső kommunikációt folytatnak, amiben a bemenő információk formális és informális utakon bejárják a rendszert, sok esetben a várt hatás elmaradását, máskor éppen nem várt hatásokat okozva. A napi rutin mellett jelen van a tanítási praxisra való folyamatos reflektálás, a problémákra való megoldások keresése. A SAILS projekt a Politechnikumban létrejött munkacsoportunkon belül egyfajta kutatás-fejlesztési folyamatot indított be. A foglalkozások tervezése, kipróbálása, a SAILS unitok adaptálása és a partnerek esettanulmányainak átnézése új szemléletet és munkamódszereket alakított ki, amelyek nem maradtak csupán a természettudomány munkacsoporton belül, hanem a különféle intézményi fórumokon, a közösségi médiában és a napi társalgásban más szakos kollégákkal is megoszthatóak voltak. A tanulási motiváció hiánya nem csak a természettudományos tantárgyak esetében okoz gondot, a tanulói teljesítmény elmaradása vagy változása is közös téma lehet. A kutatásalapú tanulás önmagában is újdonságot jelent, mivel a tanár és a tanuló egyfajta szerepcseréje történik, megváltozik a tanári irányítás jellege és a tanár-diák kapcsolat mélysége és fókusza is. A formatív értékelés motiváló ereje a tanulói személyiség középpontba állításában rejlik, a tanulási célok megbeszélése a tanulók számára nem tankönyvi tartalomjegyzék, hanem önmaguk formálásának eszköze. Képet kaphatnak a készségeik sokféle formájáról, azok fontosságáról és fejlesztési lehetőségeiről. A pedagógiai innovációkban való részvétel intézményi szint.

\section{A programok szintje}

A SAILS unitok fejlesztésére a projektpartnerek kialakítottak egy tervezési sablont, amivel igyekeztek strukturálni és validálni a kutatásalapú tanulásnak megfelelő folyamatokat. A kidolgozott foglalkozástervek (tanulási egységek) hasonló szerkezetủek, mint a kompetencia-alapú curriculumok, de formailag és tartalmilag is meg kell felelniük az IBSE módszer követelményeinek. Az óra menetét a tanulói tevékenység alapján határozzák meg, lépéseiben követik a természettudományos vizsgálatok gondolatmenetét, végighaladva annak főbb fázisain, mint például a probléma megfogalmazása, kutatási kérdés feltétele, hipotézisállítás, vizsgálat tervezése és kivitelezése, adatrögzítés és -elemzés, következtetés és magyarázat. A fejlesztendő készségek tervezését ezekhez a lépésekhez, az adott feladaton belüli konkrét tanulói tevékenységekhez kell illeszteni. Rendszerint több készség is látótérbe kerül, ezek közül az értékelés tervezése során ki kell választanunk azt a 2-3 készséget, amelyet valóban meg is tudunk figyel- 
ni, illetve amelyekkel összefüggésben teljesítményelemeket, értékelési bizonyítékokat tudunk gyüjteni.

Az IBSE foglalkozástervek legfontosabb eleme a tanári támogatás valamiféle előképének kialakítása. Ezek nem lehetnek direkt utasítások, mert azok épp a tanulói irányítást korlátoznák, szúkítenék az önálló gondolkodást. Olyan támogatásra ('scaffolding') van szükség, amely a kutatási kérdésből kiindulva további kérdések feltételét katalizálja, nem megelőlegezve a tanulók saját kérdéseit. Fontos, hogy a csoportok munkáját figyelve csak akkor adjunk segítséget, ha elakadást vagy tévútra térést tapasztalunk. A megfelelő támogatással javítható az IBSE módszer kritikus eleme, az időgazdálkodás, de segíthetjük a kitüzött tanulási célok felé való haladást is. Ez a megszokottól eltérő tanári attitüdöt és módszereket jelent, a direkt irányítás helyett a csoportmunka facilitálását helyezve előtérbe. Az 1. táblázat egy saját fejlesztésü foglalkozástervböl (Finlayson, McLoughlin, Coyle, McCabe, Lovatt és van Kampen, 2015) mutat példát a tanári támogatás lehetőségeire.

1. táblázat. A puding próbája címü foglalkozás tervezetének részlete

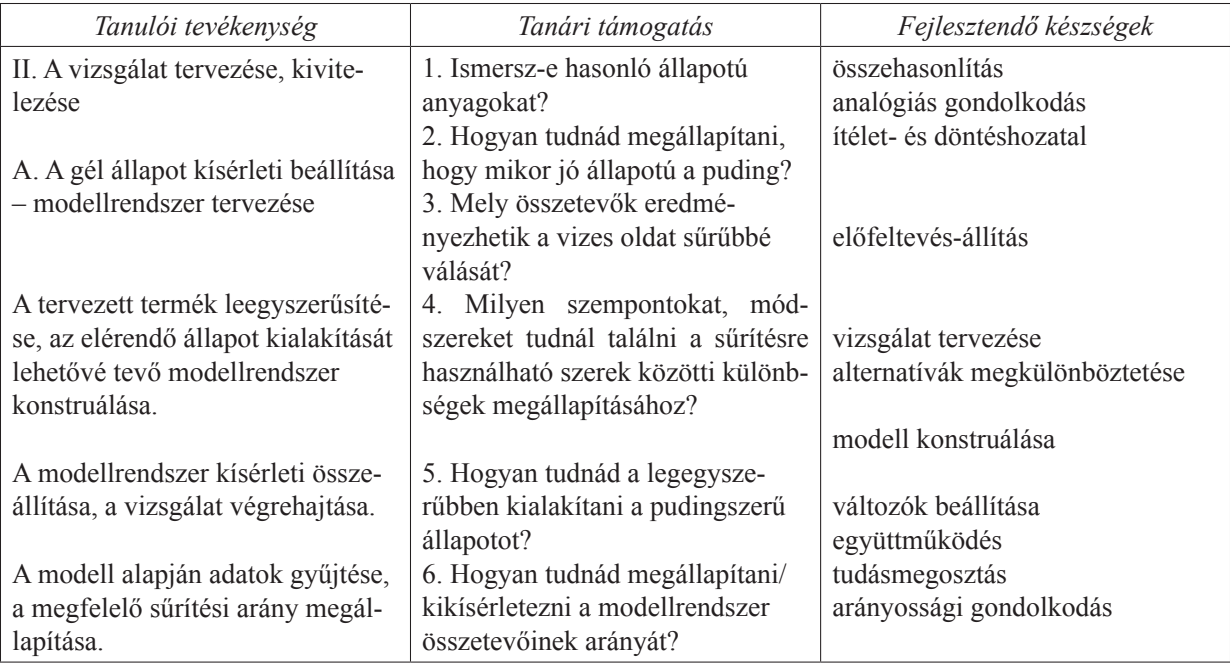

\section{A tanulói teljesítmény értékelése}

A természettudományos nevelésben az ezredforduló körül érzékelt válságjelenségek mélyebben gyökereztek annál, mintsem egyszerü tartalommódosítással, érdekesebb tananyagokkal megoldhatóak lettek volna. A világban végbemenő technológiai, gazdasági és társadalmi változások hatása elöl az oktatási rendszerek sem tudtak kitérni, a kérdés inkább az alkalmazkodás vagy ellenállás közötti választás volt. Az Európai Unió a Rocard-jelentés ajánlásainak megfelelő stratégiai választ igyekezett adni a problémára, kiemelve a deduktív helyett az induktív gondolkodás (ld. Csapó, 1998) támogatását. A kutatásalapú tanulás megfelel ennek az elvárásnak, pedagógiai hatásában túl is lépve a természettudományos nevelés szüken vett céljain. A tudáskoncepció változása, a tanuló és a tanár szerepének változása, a 21. századi készségek fejlesztésére való törekvés egy új pedagógiai paradigma felé vezet, amely megfelelö választ képes adni az információs társadalom kihívásaira (2. táblázat). 
2. táblázat. Az ipari és az információs társadalom pedagógiai paradigmáinak összehasonlitása (Voogt, 2003, 14. o.)

\begin{tabular}{|c|c|c|}
\hline Jellemzök & Ipari társadalom & Információs társadalom \\
\hline \multirow[t]{4}{*}{ Aktivitás } & Tanár által elöírt & Tanuló által meghatározott \\
\hline & Osztálytanítás & Kis létszámú csoportok \\
\hline & Behatárolt lehetőségek & Különböző lehetőségek, alternatívák \\
\hline & A haladás a program által elöírt & A haladás a tanulóhoz igazodik \\
\hline \multirow[t]{3}{*}{ Együttműködés } & Egyéni & Csoportmunka \\
\hline & Homogén csoportok & Heterogén csoportok \\
\hline & Mindenki önmagáért & Egymás támogatása \\
\hline \multirow[t]{2}{*}{ Kreativitás } & Reproduktív tanulás & Produktív tanulás \\
\hline & $\begin{array}{l}\text { Problémák már ismert megoldásainak al- } \\
\text { kalmazása }\end{array}$ & Problémákra új megoldások keresése \\
\hline \multirow[t]{4}{*}{ Integráció } & Elmélet és alkalmazás elkülönülése & Elmélet és alkalmazás kapcsolódása \\
\hline & Elkülönült tantárgyak & Tantárgyközi kapcsolatok \\
\hline & Szaktárgyi alapú & Téma-alapú \\
\hline & Egyes tanár & Tanárcsoportok \\
\hline \multirow[t]{2}{*}{ Értékelés } & Tanár által irányított & Tanuló által irányított \\
\hline & Szummatív & Diagnosztikus \\
\hline
\end{tabular}

A pedagógiai paradigmaváltás egyik kulcsterülete a tanulói teljesítmény értékelési koncepciójának és módszereinek változása. A tudás és képesség tartalmában mélyebb, kiterjedésében szélesebb értelmezést nyert. A diagnosztikus szemlélet kiterjed az ismeretek, készségek és attitüdök komponensrendszerére és fejlődési folyamatára. A tanároknak tapasztalt diagnosztákká kell válniuk, egyénenként követni tanulóik fejlődését, és folyamatos visszajelzésekkel segíteni őket a továbbhaladásban. A közoktatás rendszerének tömegessége és nehézkessége számos akadályt gördít ennek megvalósulása elé, de a müködőképes minták és megoldások segíthetnek ezek elhárításában. A SAILS projekt során kialakított stratégiák ezt a fejlesztő szemléletü, formatív értékelést támogatják.

A formatív értékelés jellemzői:

- A tanulás lehetséges eredményei előzetesen világosan meghatározottak.

- A módszerek tudatosan megtervezettek.

- Alkalmas a problémamegoldás folyamatának való valós idejű nyomon követésére.

- A visszatekintés, reflektálás alapvető eleme.

- Bevonja a tanulókat a tanulási célok meghatározásába, az értékelés megtervezésébe és kivitelezésébe.

- A tanulási folyamat szabályozására irányul.

Előnyei:

- Növeli a tanulás iránti motivációt.

- Megerősíti a tanulókat abban, hogy mindenki képes fejlődni.

- Ráirányítja a tanulók figyelmét arra, mit és hogyan tanulnak.

- Ösztönzi a tanulókat az önértékelésre.

- Lehetővé teszi a diákoknak megismerni és megérteni a követelményeket, ezzel is segítve azt, hogy azok az ö céljaikká is váljanak (Black és Wiliam, 1998a).

A SAILS projekt során kidolgozott foglalkozástervek és az alkalmazás tapasztalatait összegző esettanulmányok konkrét eszközöket és javaslatokat tartalmaznak az egyes készségek formatív értékelésére. 


\section{A természettudományos gondolkodás fejlesztése}

A kutatásalapú tanulás egyik fö célja a természettudományos gondolkodás fejlesztése. Amint Lawson rámutatott: „A magasabb rendü tudományos gondolkodás fejlesztésében nem annak van jelentösége, amit tanítunk, inkább annak, ahogyan tanítunk... Meg kell tanítanunk a tanulóknak egy sor tudományos vizsgálati módszert, és el kell sajátíttatnunk azokat a magasabb rendü gondolkodási múveleteket, amelyek alapján a tanulók képessé válnak a tények és adatok elemzésére, természettudományos vizsgálatok tervezésére, magyarázatok megfogalmazására, tudományos modellek kidolgozására és alkalmazására." (Lawson, 1978, 23. o.). A kutatómunka nemcsak a természettudományos ismereteket kívánja elsajátíttatni a tanulókkal, hanem a tudományos gondolkodás müködését (1. ábra) annak gyakorlásával igyekszik megismertetni, alkalmazható készséggé formálni. Hátterében az a meggyőződés áll, hogy a tényeken és bizonyításon alapuló gondolkodásmód mindenki számára hasznos, segíthet a mindennapi élet problémáinak megoldásában.
A kutatásalapú tanulás egyik fó célja a természettudományos gondolkodás fejlesztése. Amint Lawson rámutatott: „A magasabb rendú tudományos gondolkodás fejlesztésében nem annak van jelentôsége, amit tanítunk, inkább annak, ahogyan tanitunk... Meg kell tanitanunk a tanulóknak egy sor tudományos vizsgálati módszert, és el kell sajátíttatnunk azokat a magasabb rendú gondolkodási múveleteket, amelyek alapján a tanulók képessé válnak a tények és adatok elemzésére, természettudományos vizsgálatok tervezésére, magyarázatok megfogalmazására, tudományos modellek kidolgozására és alkalmazására." (Lawson, 1978, 23. o.).

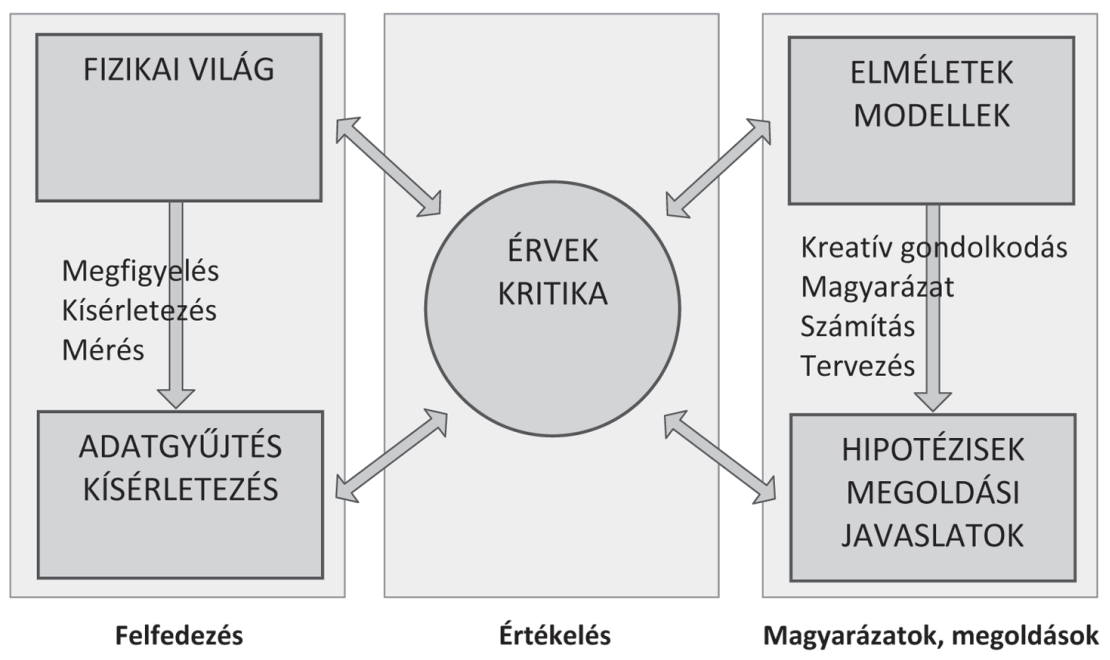

1. ábra. A természettudomány müködési modellje (National Research Council, 2012, 45. o.) 
A természettudományos tudás koncepcióján belül jól elkülöníthető a megismerési útra jellemző procedurális, illetve a megismerés eredményét górcső alá vevő episztemikus tudás. Előbbi a természettudományos vizsgálatok tervezéséhez és kivitelezéséhez, az adatok elemzéséhez és értékeléséhez szükséges, fejlődési modellje az alábbi elemeket/ szinteket határozza meg (Lubben és Millar, 1996):

- Méréssel kapcsolatos tudás (mennyiségi, minőségi szempontok), mértékrendszerek használata, diszkrét és folyamatos változók.

- A bizonytalanságok felismerésére és minimalizálására szolgáló eljárások ismerete (többszöri mérés, átlagolás).

- A megismételhetőség biztosítása (a megismételt kísérletek egyezése), az adatpontosság elérése (a mért mennyiség és a mért értékek egyezése).

- Az adatrögzítés és ábrázolás egyszerűbb módjainak ismerete (táblázatok, grafikonok megfelelö használata).

- A változó fogalmának ismerete, független és függő változó megkülönböztetése.

- A változók beállításának képessége, a kísérletekben játszott szerepének felismerése, kísérleti kombinációk kialakítása a megbízhatóbb eredmény érdekében, a lehetséges oksági viszonyok felismerése.

- Egy adott természettudományos kérdéshez megfelelően kapcsolódó vizsgálat tervezése (kísérleti, terepmunka vagy egyéb kutatás).

Amíg a procedurális tudás arról szól, mit és hogyan tegyünk, addig az episztemikus tudás arra keresi a választ, hogy miért szükségesek, illetve milyen eredményre vezethetnek ezek a tevékenységek. Néhány fejlesztendő episztemikus tudáselem (Osborne, 2013):

- A természettudományos megfigyelések, tények, hipotézisek, modellek és elméletek jellemzői.

- A tudományos állítások adatokkal és magyarázatokkal való alátámasztásának szükségessége.

- A tudományos hipotézis tesztelhető előrejelzés kialakításában játszott szerepe.

- A mérési pontosság és a tudományos ismeretek megbízhatósága közötti összefüggés.

- A fizikai és az absztrakt modellek szerepe, használhatóságuk és korlátaik.

- Az együttmüködés, a kritika és a tudóstársak bírálatának jelentősége a tudományos állítások megbízhatóságának növelésében.

Egy tudományos szöveg olvasásakor különbséget kell tennünk a megfigyelési eredmény, az előfeltevés és a tényállítás között. Ez a tudás szükséges ahhoz, hogy értékelni tudjuk a tudományos állításokat. Mibenléte azonban nehezen deklarálható, inkább az alkalmazása közben a tanulóknak nyújtott segítséggel fejleszthető (Kind, 2013; OECD, 2012).

\section{A kutatási készségek fejlődési indikátorai}

A kutatási készségek fejlődésének értékeléséhez meg kell határozni a fejlődés legfontosabb mutatóit (Osborne és Ratcliffe, 2002). A SAILS tanulási egységekhez kidolgozott értékelési eszközökben szöveges meghatározások találhatók az egyes készségek értelmezésével és fejlődési szintjével kapcsolatban. A különböző jellegű foglalkozások és az eltérő szerzői értelmezések miatt ezek között akár jelentős tartalmi és mélységbeli különbségek lehetnek. A foglalkozások adaptálását, egy tanulócsoportban való alkalmazását ez nem akadályozza, de az eredmények megosztásában, a tapasztalatok összegzésében nehézséget jelenthet. A kutatások ezen a területen is feltártak olyan fejlődési indikátorokat, amelyek figyelembe vételével objektívebbé tehetők a készségfejlődés szintjeit 
leíró skálák. A kutatási készségek lehetséges fejlődési indikátorait az alábbi felsorolás foglalja össze.

1. Kérdésfeltevés

- A természettudományosan vizsgálható kérdések felismerése.

- A vizsgálat lényegi kérdésének felismerése, megfogalmazása.

- Konkrét kérdések megkülönböztetése vizsgálhatóságuk alapján.

- A nem vizsgálható kérdések átfogalmazása konkrét vizsgálatra irányuló kutató kérdésre

- egymásba épülö, egymásból következő kérdések megfogalmazása.

2. Hipotézis megfogalmazása

- Tényekre alapozottság, lényeges tulajdonságok, körülmények figyelembe vétele.

- Korábbi tapasztalatokból levont következtetés, ismert fogalmak beépítése.

- Nehezen ellenőrizhető jelenségek végbemenetelére vonatkozó hipotézis megfogalmazása.

- Jelenségek vizsgálati módszereire vonatkozó elképzelés.

- Adott tényre, jelenségre vonatkozó többféle lehetséges elképzelés figyelembe vétele.

- Az előfeltevések, elképzelések bizonyításának igénye.

3. Megfigyelés

- Objektumok, anyagok közötti hasonlóságok és különbségek felismerése.

- A különbségek részletes és világos megfogalmazása.

- Részleges hasonlóság felismerése különböző objektumok esetében.

- A vizsgált problémával összefüggő megfigyelési eredmények felismerése.

- Többféle érzékszerven alapuló megfigyelés.

- Megfigyelési eszközök használata.

4. Kísérlettervezés, kivitelezés

- Alapvető elméletekből való kiindulás hiányos információk esetén, vagy továbbgondolást igénylő esetekben.

- Adott kérdéssor alapján kísérlet tervezése.

- Megfelelö kísérleti lépéssor megtervezése.

- Beállítandó (függő) változók és rögzített változók azonosítása.

- Vizsgálati terv készítése, független, függő és rögzített változók beállítása.

- A kísérlet sikeressége érdekében keresendő vagy mérendő adat azonosítása.

- Tervezett és végbement/végrehajtott vizsgálatok összevetése.

5. Következtetés

- Az eredmények összevetése a kiinduló kérdéssel.

- Az eredmények összevetése az elörejelzésekkel.

- Változók közötti összefüggések bemutatása.

- A megfigyelések és mérések jellemzőinek, irányának bemutatása.

- A kapott tényeket, adatokat összegző következtetések megfogalmazása.

- A következtetések eseti jellegének, felmerülő új tények esetén való változtathatóságának felismerése.

\section{Példák a kutatási készségek értékelésére}

Ebben a részben azt mutatjuk be, hogy a projekt során elkészített tanulási egységek keretében miképpen lehet értékelni a korábban bemutatott kutatási készségeket. Az itt következő táblázatok címében megjelöljük, hogy milyen készség értékeléséről van szó, és zárójelben megadjuk a megfelelő tanulási egység megnevezését. Különböző tanulási egységek példáját felhasználva mutatjuk be a tanulói kutatómunka fontosabb fázisaiban 
alkalmazott készségek értékelésének szempontjait. A vizsgálat tervezése (3. táblázat), a vizsgálat kivitelezése (4. táblázat), az adatok gyüjtése, elemzése (5. táblázat) és a koherens érvelés (6. táblázat) fejlődésének értékelését egyaránt egy négyfokozatú skálán végezhetjük el.

3. táblázat. Vizsgálat tervezése (Élelmiszerek vizsgálata-Food and food labels)

\begin{tabular}{|c|c|c|c|}
\hline \multicolumn{4}{|c|}{ Tanulói teljesítmény } \\
\hline Kezdö & Fejlödö & Konszolidálódó & Kiterjedt \\
\hline $\begin{array}{l}\text { A vizsgálat tervezésére } \\
\text { önálló ötlet nincs, a közö- } \\
\text { sen kialakított munkame- } \\
\text { netbe való aktív bekap- } \\
\text { csolódás. Az eredmény } \\
\text { kiszámításának passzív } \\
\text { követése. }\end{array}$ & $\begin{array}{l}\text { Önálló ötletek a vizsgálat } \\
\text { tervezésére, a megfelelö } \\
\text { módszer kiválasztása, } \\
\text { de a végrehajtás még bi- } \\
\text { zonytalan. } \\
\text { Az eredmény kiszámítása } \\
\text { segítséggel. }\end{array}$ & $\begin{array}{l}\text { A megfelelő vizsgálati } \\
\text { módszer kiválasztása, en- } \\
\text { nek indoklása, a munka- } \\
\text { menet részleteinek meg- } \\
\text { felelö tervezése. } \\
\text { Az eredmény helyes ki- } \\
\text { számítása. }\end{array}$ & $\begin{array}{l}\text { A megfelelő vizsgálati } \\
\text { módszer kiválasztása, en- } \\
\text { nek indoklása, a munka- } \\
\text { menet részleteinek a vár- } \\
\text { ható hibalehetőségekre, } \\
\text { veszélyekre is kiterjedő } \\
\text { tervezése. } \\
\text { Az eredmény gyors és } \\
\text { pontos kiszámítása. }\end{array}$ \\
\hline
\end{tabular}

4. táblázat. Vizsgálat kivitelezése (Természetes szelekció - Natural selection)

\begin{tabular}{|c|c|c|c|}
\hline \multicolumn{4}{|c|}{ Tanulói teljesitmény } \\
\hline Kezdö & Fejlödö & Konszolidálódó & Kiterjedt \\
\hline $\begin{array}{l}\text { A feladat leírását nem } \\
\text { képes önállóan értelmez- } \\
\text { ni, de társai segítségével } \\
\text { részt tud venni a végre- } \\
\text { hajtásban. } \\
\text { Az egyes lépések célját, } \\
\text { jelentőségét képes fel- } \\
\text { mérni, de a feladat egé- } \\
\text { szét nem látja át. }\end{array}$ & $\begin{array}{l}\text { A feladat leírásának értel- } \\
\text { mezésében aktívan részt } \\
\text { vesz, hibáit képes önma- } \\
\text { ga is korrigálni. A végre- } \\
\text { hajtásban részfeladatokat } \\
\text { vállal. A feladat célját, } \\
\text { menetét vázlatosan, de } \\
\text { helyesen látja át. }\end{array}$ & $\begin{array}{l}\text { A feladat értelmezésében } \\
\text { aktívan részt vesz, szük- } \\
\text { ség esetén segíti társait is. } \\
\text { A végrehajtásban folya- } \\
\text { matosan és megbízhatóan } \\
\text { részt vesz. } \\
\text { Törekszik az utasítások } \\
\text { gyors és pontos végrehaj- } \\
\text { tására. }\end{array}$ & $\begin{array}{l}\text { A feladat célját és mene- } \\
\text { tét gyorsan és pontosan } \\
\text { átlátja. } \\
\text { Segíti és irányítja társait } \\
\text { az értelmezésekben és a } \\
\text { kivitelezésben. Képes al- } \\
\text { ternatívákra javaslatokat } \\
\text { tenni a siker érdekében. }\end{array}$ \\
\hline
\end{tabular}

5. táblázat. Adatok gyüjtése, elemzése (Élelmiszerek vizsgálata-Food and food labels)

\begin{tabular}{|c|c|c|c|}
\hline \multicolumn{4}{|c|}{ Tanulói teljesitmény } \\
\hline Kezdö & Fejlödö & Konszolidálódó & Kiterjedt \\
\hline $\begin{array}{l}\text { A megfelelö adat kivá- } \\
\text { lasztása nem minden } \\
\text { esetben sikeres, kevés az } \\
\text { adatok mennyisége is. } \\
\text { Az adatok felhasználása } \\
\text { nem következetesen kap- } \\
\text { csolódik a feladathoz. }\end{array}$ & $\begin{array}{l}\text { A megfelelő adat kivá- } \\
\text { lasztása többnyire sike- } \\
\text { res, az adatok mennyi- } \\
\text { sége is megfelelő, de a } \\
\text { feladathoz való kapcsoló- } \\
\text { dások, a célszerű adatfel- } \\
\text { használás esetleges. }\end{array}$ & $\begin{array}{l}\text { A megfelelő adat kivá- } \\
\text { lasztása magabiztosan } \\
\text { történik, az adatok meny- } \\
\text { nyisége megfelelö, fel- } \\
\text { használásuk célszerüen } \\
\text { kapcsolódik a feladathoz. }\end{array}$ & $\begin{array}{l}\text { Az adatok kiválasztása } \\
\text { és felhasználása nagy } \\
\text { biztonsággal és gyorsan } \\
\text { történik, a feladat végre- } \\
\text { hajtása során a felhasz- } \\
\text { nálásuk dominál. Megje- } \\
\text { lenik az adatok megbíz- } \\
\text { hatóságával, kapcsolatos } \\
\text { kritikai szemlélet is. }\end{array}$ \\
\hline
\end{tabular}


Veres Gábor: Gondolkodás- és képességfejlesztés: kihívások és megoldások a SAILS projektben

6. táblázat. Koherens érvelés (A növények táplálkozása - Plant nutrition)

\begin{tabular}{|c|c|c|c|}
\hline \multicolumn{4}{|c|}{ Tanulói teljesítmény } \\
\hline Kezdö & Fejlödö & Konszolidálódó & Kiterjedt \\
\hline $\begin{array}{l}\text { Nem képes tudomá- } \\
\text { nyos érveket megfo- } \\
\text { galmazni a csoport } \\
\text { által javasolt tervek } \\
\text { mellett vagy ellen. } \\
\text { Esetenként képes } \\
\text { az adatok alapján } \\
\text { következtetéseket } \\
\text { levonni, de ezt nem } \\
\text { tudja tudományos } \\
\text { érvekkel alátámasz- } \\
\text { tani. }\end{array}$ & $\begin{array}{l}\text { Tudományos érvekkel alá } \\
\text { tudja támasztani az erede- } \\
\text { ti kísérleti tervet és a cso- } \\
\text { port által megfogalmazott } \\
\text { különböző alternatívákat, } \\
\text { de a gondolatmenete nem } \\
\text { mindig pontos. } \\
\text { Képes az adatok elemzésé- } \\
\text { re, esetenként tudományos } \\
\text { érvekkel való alátámasz- } \\
\text { tására, de még nehézséget } \\
\text { okoznak számára a kísér- } \\
\text { leti hibák és a statisztikai } \\
\text { elemzés. }\end{array}$ & $\begin{array}{l}\text { Pontos tudományos } \\
\text { érvekkel tudja alátá- } \\
\text { masztani a csoport által } \\
\text { megfogalmazott kísérleti } \\
\text { terveket. } \\
\text { Képes az adatok elemzé- } \\
\text { sére, a következtetések } \\
\text { tudományos érvekkel } \\
\text { való alátámasztására és a } \\
\text { kísérleti hibák megelözé- } \\
\text { sére, csökkentésére. }\end{array}$ & $\begin{array}{l}\text { Pontos tudományos érvek- } \\
\text { kel tudja alátámasztani a } \\
\text { csoport által megfogalma- } \\
\text { zott kísérleti terveket és ké- } \\
\text { pes mások terveinek kritikus } \\
\text { elemzésére. } \\
\text { Kritikusan tudja elemezni az } \\
\text { adatokat, statisztikai szem- } \\
\text { léletet is alkalmaz, ellenőrzi } \\
\text { a kísérleti hibákat, döntéseit } \\
\text { minden esetben tudományos } \\
\text { érvekkel tudja igazolni. }\end{array}$ \\
\hline
\end{tabular}

\section{A 21. századi készségek fejlesztése}

A SAILS projekt során a természettudományos készségek fejlesztése mellett nagy hangsúlyt kapott az is, hogy a tanulói tevékenységnek milyen tágabb hatása lehet, hogyan járulhat hozzá a kutatásalapú tanulás az értelmi képességek szélesebb körének fejlesztéséhez. Ilyenek például azok a készségek, amelyeket összefoglaló néven gyakran 21. századi készségeknek neveznek. Több elméleti keretrendszer (pl. Partnership for 21st century skills - P21; Assessment and Teaching of 21st Century Skills-ATCS) is leírja ezeket, melyek általános kategóriáit készségek, attitüdök, értékek és etikai elvek összességeként értelmezhetjük. A további elemzések, valamint az EU, az OECD és az UNESCO tanulmányainak eredményei a 7. táblázat szerint összegezhetők.

7. táblázat. A 21. századi készségek listája az oktatási dokumentumokban

\begin{tabular}{|c|c|c|c|}
\hline $\begin{array}{c}\text { Mindegyik } \\
\text { keretrendszerben }\end{array}$ & $\begin{array}{c}\text { Legtöbb } \\
\text { keretrendszerben }\end{array}$ & Néhány keretrendszerben & $\begin{array}{c}\text { Egyetlen } \\
\text { keretrendszerben }\end{array}$ \\
\hline $\begin{array}{l}\text { Együttműködés } \\
\text { Kommunikáció } \\
\text { IKT-jártasság } \\
\text { Társadalmi és/vagy } \\
\text { kulturális készségek }\end{array}$ & $\begin{array}{l}\text { Kreativitás } \\
\text { Kritikus gondolkodás } \\
\text { Problémamegoldás } \\
\text { Eredményesség/ } \\
\text { Produktivitás }\end{array}$ & $\begin{array}{l}\text { A tanulás tanulása } \\
\text { Önirányítás } \\
\text { Tervezés } \\
\text { Rugalmasság és alkal- } \\
\text { mazkodóképesség }\end{array}$ & $\begin{array}{l}\text { Kockázatvállalás } \\
\text { Konfliktuskezelés, -meg- } \\
\text { oldás } \\
\text { Kezdeményező- és vál- } \\
\text { lalkozási készség }\end{array}$ \\
\hline
\end{tabular}

A 21. századi készségek fejlesztését támogató tanári kompetenciák $(P 21)$ :

- A 21. századi készségek fontosságának és a napi pedagógiai munkába való integrálási lehetőségeinek megértése.

- A tananyag mély megértése és a problémamegoldás, kritikus gondolkodás és más 21. századi készségek fejlesztése közötti összefüggés megértése.

- A tanulók egyéni tanulási stílusának és adottságainak felismerési képessége.

- A 21. századi technikai lehetőségek (pl. médiaforrások, számítógéppel segített tanulás, közösségi média) használata az osztálytermi munkában.

- A tudásmegosztás lehetőségeinek kiaknázása, a szakértőkkel és más, iskolán kívüli közösségekkel való személyes és virtuális információcsere. 
- A készségfejlesztés kezdése kis lépésekkel, rövid és egyszerü projektekkel, amelyek segítik a 21. századi készségek integrálási módjának megtalálását a tantárgyi munkába.

- Az együttmüködés, a hálózatépítés erősítése iskolán belül és iskolák között, valamint a kutatókkal és szakértőkkel, társadalmi szervezetekkel.

A felsorolt tanári kompetenciák szükségesek az IBSE módszer sikeréhez és fenntarthatóságához, de az alkalmazás egyben fejleszti is ezeket a készségeket. A projekt keretében kidolgozott foglalkozástervekben a 21. század készségeire is szerepeltek értékelési minták. A 8-11. táblázatok ezekre mutatnak példákat az előző részben megismert rendszerben.

8. táblázat. Együttmüködés (Természetes szelekció - Natural selection)

\begin{tabular}{|c|c|c|c|}
\hline \multicolumn{4}{|c|}{ Tanulói teljesitmény } \\
\hline Kezdö & Fejlödö & Konszolidálódó & Kiterjedt \\
\hline $\begin{array}{l}\text { A csoportmunkába képes } \\
\text { bekapcsolódni, de mun- } \\
\text { kája nem folyamatos. } \\
\text { A rábízott feladatokat ké- } \\
\text { pes elvégezni, de önálló- } \\
\text { an nem vállalkozik. }\end{array}$ & $\begin{array}{l}\text { A csoportmunkában vál- } \\
\text { tozó intenzitással, de fo- } \\
\text { lyamatosan részt vesz. } \\
\text { Esetenként önállóan is } \\
\text { vállal részfeladatokat. }\end{array}$ & $\begin{array}{l}\text { A csoportmunkában fo- } \\
\text { lyamatosan és hatéko- } \\
\text { nyan részt vesz. } \\
\text { Gyakran vállal önálló- } \\
\text { an is feladatokat, ezeket } \\
\text { egyezteti társaival. }\end{array}$ & $\begin{array}{l}\text { A csoportmunkában } \\
\text { rendszerint irányító sze- } \\
\text { repet játszik, hatékonyan } \\
\text { szervezi, segíti társai } \\
\text { munkáját. }\end{array}$ \\
\hline
\end{tabular}

9. táblázat. Kommunikáció (Élelmiszerek vizsgálata - Food and food labels)

\begin{tabular}{|c|c|c|c|}
\hline \multicolumn{4}{|c|}{ Tanulói teljesitmény } \\
\hline Kezdö & Fejlödö & Konszolidálódó & Kiterjedt \\
\hline $\begin{array}{l}\text { Az írásbeli kommuniká- } \\
\text { ció bátortalan, hiányos, } \\
\text { vagy teljesen hiányzik. } \\
\text { Szóban folyamatosabb, } \\
\text { de nem célratörő a kom- } \\
\text { munikáció. }\end{array}$ & $\begin{array}{l}\text { Az írásbeli kommuniká- } \\
\text { ció folyamatos, de kissé } \\
\text { hiányos, önálló vélemény } \\
\text { megfogalmazására törek- } \\
\text { szik, de még bizonytalan. } \\
\text { Szóban folyamatosabb a } \\
\text { kommunikáció, általában } \\
\text { célszerü is. }\end{array}$ & $\begin{array}{l}\text { Az írásbeli kommuniká- } \\
\text { ció folyamatos, az önálló } \\
\text { vélemény megfogalma- } \\
\text { zása magabiztos. } \\
\text { Szóban folyamatos és } \\
\text { célszerű a kommunikáció, } \\
\text { de az érvelés nem minden } \\
\text { esetben hatékony. Mások } \\
\text { meghallgatása, esetenként } \\
\text { reflektálás is. }\end{array}$ & $\begin{array}{l}\text { Az írásbeli kommuniká- } \\
\text { ció folyamatos, az önálló } \\
\text { vélemény megfogalma- } \\
\text { zása magabiztos. } \\
\text { Szóban folyamatos és } \\
\text { célszerű kommunikáció, } \\
\text { hatékony érvelés. } \\
\text { Mások meghallgatása, } \\
\text { reflektálás, rugalmasság, } \\
\text { indokolt esetben eltérö } \\
\text { vélemény elfogadása. }\end{array}$ \\
\hline
\end{tabular}

10. táblázat. Kritikus gondolkodás (Élelmiszerek vizsgálata-Food and food labels)

\begin{tabular}{|c|c|c|c|}
\hline \multicolumn{4}{|c|}{ Tanulói teljesitmény } \\
\hline Kezdö & Fejlödö & Konszolidálódó & Kiterjedt \\
\hline $\begin{array}{l}\text { Egy-egy tápanyag ese- } \\
\text { tében elegendő számú } \\
\text { élelmiszerkártya többsé- } \\
\text { gében megfelelö sorba } \\
\text { rendezése, további követ- } \\
\text { keztetés nélkül. }\end{array}$ & $\begin{array}{l}\text { Egy-egy tápanyag ese- } \\
\text { tében elegendő számú } \\
\text { élelmiszerkártya meg- } \\
\text { felelő sorba rendezése, } \\
\text { minőségi következteté- } \\
\text { sek és ítéletek megfo- } \\
\text { galmazása tápanyagcso- } \\
\text { portokra, esetenként két } \\
\text { tápanyagegyüttes figye- } \\
\text { lembe vételével. }\end{array}$ & $\begin{array}{l}\text { Valamennyi rendelkezés- } \\
\text { re álló élelmiszerkártya } \\
\text { többségében helyes sorba } \\
\text { rendezése, minőségi kö- } \\
\text { vetkeztetések és itéletek } \\
\text { megfogalmazása 2-3 } \\
\text { tápanyagcsoport együttes } \\
\text { figyelembe vételével. } \\
\text { Mennyiségi szempontok } \\
\text { felvetése a vitában. }\end{array}$ & $\begin{array}{l}\text { Valamennyi rendelkezés- } \\
\text { re álló élelmiszerkártya } \\
\text { helyes sorba rendezése, } \\
\text { helyes minőségi követ- } \\
\text { keztetések és ítéletek } \\
\text { megfogalmazása az } \\
\text { összes vizsgált táp- } \\
\text { anyagcsoport együttes } \\
\text { figyelembe vételével. } \\
\text { Mennyiségi szempontok } \\
\text { érvényesítése a vitában. }\end{array}$ \\
\hline
\end{tabular}


Veres Gábor: Gondolkodás- és képességfejlesztés: kihívások és megoldások a SAILS projektben

11. táblázat. Ítéletalkotás (Élelmiszerek vizsgálata - Food and food labels)

\begin{tabular}{|c|c|c|c|}
\hline \multicolumn{4}{|c|}{ Tanulói teljesitmény } \\
\hline Kezdö & Fejlödö & Konszolidálódó & Kiterjedt \\
\hline $\begin{array}{l}\text { Ötletek esetleges, szóbeli } \\
\text { megfogalmazása, írásbeli } \\
\text { közlés nélkül. } \\
\text { Másokra való reagálás } \\
\text { nem jellemzö. }\end{array}$ & $\begin{array}{l}\text { Ötletek szóbeli megfo- } \\
\text { galmazása, esetenként } \\
\text { írásban is. } \\
\text { Esetenként másokra való } \\
\text { reagálás is. }\end{array}$ & $\begin{array}{l}\text { Az ötletek, vélemények } \\
\text { ítéletként való, határozott } \\
\text { megfogalmazása szóban } \\
\text { és írásban, esetenként } \\
\text { érvekkel való alátámasz- } \\
\text { tása. } \\
\text { Vitában kritikus álláspont } \\
\text { képviselete. }\end{array}$ & $\begin{array}{l}\text { Az ötletek, vélemények } \\
\text { ítéletként való, határozott } \\
\text { megfogalmazása szóban } \\
\text { és írásban, minden eset- } \\
\text { ben megfelelő érvekkel } \\
\text { való alátámasztása. } \\
\text { Mások érveinek szükség } \\
\text { szerint kritikus vagy elfo- } \\
\text { gadó szemlélete. }\end{array}$ \\
\hline
\end{tabular}

\section{Összegzés}

A 21. század technológiai és társadalmi változásai elkerülhetetlenül átformálják a pedagógiai rendszereket is. Az oktatási intézmények múlt századi müködési modelljét adaptálni kell az új kihívásokhoz, a tudás, a tanulás új paradigmáihoz. A természettudományos nevelés ebből a modernizációból részt vállalva kínálja a tanulók aktív bevonásával müködő kutatásalapú tanulás módszerét.

A SAILS projektben kidolgozott foglalkozásmintákban központi szerepet kapnak a kutatási készségek és a 21. században egyre fontosabbá váló szociális és kommunikációs készségek. A foglalkozások kipróbálásával felhalmozott tapasztalatokra épülve konkrét gyakorlati módszerek és eszközök váltak átvehetővé. A vizsgálatok leírása mellett ezekben a tanulói teljesítmény értékelésére szolgáló eszközök is a tanárok rendelkezésére állnak. A foglalkozások során visszajelzések adhatók a tanulók számára, amelyek segítik őket tudásuk értékelésében és a személyiségük fejlődésében. A formatív értékelés alkalmazása során a tanárok is mélyebben megérthetik tanítványaik gondolkodását, tanulási szükségleteit. Visszahatásként az értékelési eszközök folyamatos korrekciója is megtörténhet, így egyre pontosabban illeszkedhetnek a készségek fejlödési szintjeihez és indikátoraihoz. Ez a tanulásfelfogás és értékelési gyakorlat a tanárok közötti tudásmegosztás révén hatással lehet az oktatási rendszer pedagógiai kultúrájára.

\section{Irodalom}

ATCS (2010): White Paper about 21st century skills of ATCS. University of Melbourne.

Black, P. és Wiliam, D (1998a): Assessment and Classroom Learning. Assessment in Education, 5. 1. sz. 7-71. DOI: 10.1080/0969595980050102

Black, P. és Wiliam, D. (1998b): Inside the Black Box. Raising Standards through Classroom Assessment. Phi Delta Kappan, 80. 2. sz. 139-148. DOI: 10.1177/003172171009200119

Csapó Benő (1998): Az új tudás képződésének eszközei: az induktív gondolkodás. In: Csapó Benő (szerk.): Az iskolai tudás. Osiris Kiadó, Budapest. 251-280.

Csapó Benő (2003): A képességek fejlödése és iskolai fejlesztése. Akadémiai Kiadó, Budapest.
Csapó Benő, Csíkos Csaba és Korom Erzsébet (2016): Értékelés a kutatásalapú természettudomány-tanulásban - a SAILS projekt. Iskolakultúra, 26. 3. sz. 3-16.

D. Molnár Éva (2013): Tudatos fejlődés. Az önszabályozott tanulás elmélete és gyakorlata. Akadémiai Kiadó, Budapest.

Dede, C. (2010): Comparing Frameworks for 21st Century Skills. In: Bellanca, J. és Brandt, R. (szerk.): 21st Century Skills. Solution Tree Press, Bloomington, IN. 51-76.

Finlayson, O., McLoughlin, E., Coyle, E., McCabe, D., Lovatt, J. és van Kampen, P. (2015, szerk.): SAILS inquiry and assessment units. Volume 1. 93-103. 
Halász Gábor (2009): Tanulás, tanuláskutatás és oktatáspolitika. Pedagógusképzés, 7. 2-3. sz. 7-36.

Kind, P. M. (2013): Establishing assessment scales using a novel disciplinary rationale for scientific reasoning. Journal of Research in Science Teaching, $\mathbf{5 0}$. 5. sz. 530-560. DOI: 10.1002/tea.21086

Lawson, A. E. (1978): The development and validation of a classroom test of formal reasoning, Journal of Research in Science Teaching, 15. 1. sz. 11-24. DOI: 10.1002/tea.3660150103

Lubben, F., és Millar, R. (1996): Children's ideas about the reliability of experimental data. International Journal of Science Education, 18. 8. sz. 955-968. DOI: 10.1080/0950069960180807

National Research Council (2012): A framework for K-12 science education: Practices, crosscutting concepts, and core ideas. Committee on a Conceptual Framework for New K-12 Science Education Standards. Board on Science Education, Division of Behavioral and Social Sciences and Education, The National Academies Press, Washington, DC. DOI: $10.17226 / 13165$

\section{Jegyzet}

${ }^{1}$ A tanulási egységek (unitok) és az esettanulmányok összegzése angol nyelven elérhető itt: http://results. sails-project.eu/units
OECD (2012): The PISA 2015 Assessment framework: Key competencies in reading, mathematics and science. OECD, Paris.

Osborne, J. (2013): The 21st century challenge for science education: Assessing scientific reasoning. Thinking skills and creativity, 10. sz. 265-279. DOI: 10.1016/j.tsc.2013.07.006

Osborne, J. F. és Ratcliffe, M. (2002): Developing effective methods of assessing ideas and evidence. School Science Review, 83. 305. sz. 113-123.

Partnership for 21th century learning (P21): Framework for 21st century learning. Science Maps.

Rocard, M., Csermely P., Jorde, D., Lenzen, D., Walberg-Henriksson, H. és Hemmo, V. (2007): Science education NOW: A renewed pedagogy for the future of Europe. European Commission, Brussels.

Voogt, J. (2003): Consequences of ICT for aims, contents, processes and environments of learning. In: van den Akker, J., Kuiper, W. és Hameyer, U. (szerk.): Curriculum landscapes and trends. Kluwer, Dordrecht. 217-236. DOI: 10.1007/978-94-017-1205-7 